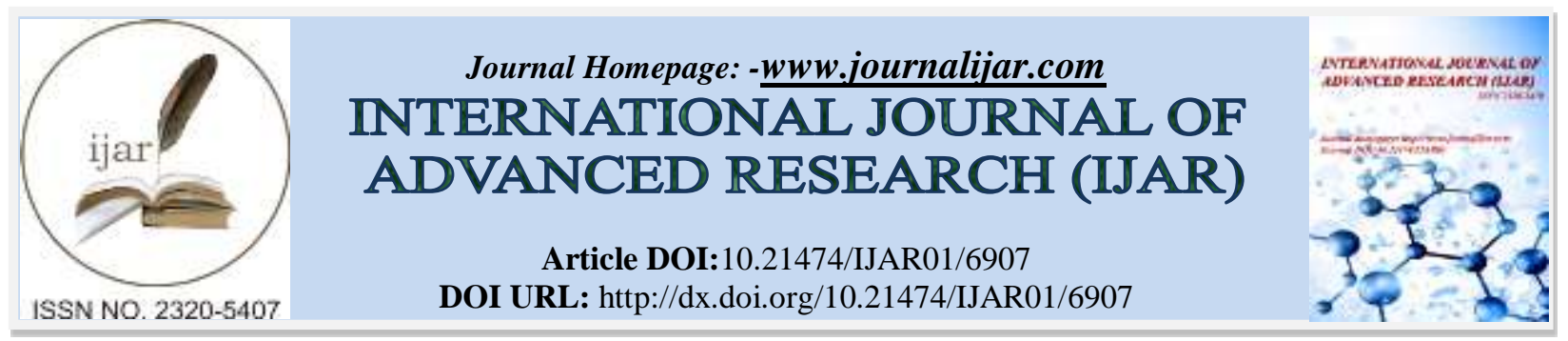

RESEARCH ARTICLE

\title{
INCREASING EMPLOYEES' EFFECTIVENESS USING BALANCED SCORECARD, DIAGNOSTIC STUDY.
}

\section{Radwan Choughri.}

Jinan University.

\section{Manuscript Info}

Manuscript History

Received: 11 February 2018

Final Accepted: 13 March 2018

Published: April 2018

\section{Abstract}

The goal of this study is to test whether a balanced scorecard can increase employees' effectiveness taking into consideration five demographic factors. To achieve this goal, a questionnaire of 55 questions was made depending on a series of meetings for all employees and managers and depending on the current situation and current needs of the companies. A random sample of 50 persons covering all departments of maintenance, accounting, follow up, programming and sails was taken. The analytical-descriptive method is used

The first part is theoretical: It depends on the descriptive method to give an integral idea depending on the most important related books, journals, references, and former studies.

The second part is applicable depended on in-depth interviews, a focused group so that a questionnaire was made depending on the real situation and real problems facing the companies (Technological Companies working in North Lebanon). The questionnaire was analyzed depending on the techniques and the suitable statistical program.

The main result is that BSC helps in increasing employees' effectiveness \%51. Depending on this many recommendations were set and the most important recommendation is to apply BSC and focus most on the internal processes perspective because of its great role in increasing effectiveness.

Copy Right, IJAR, 2018,. All rights reserved.

\section{Significance of the Study:-}

The importance of this research comes first from the vital necessity of increasing employees' effectiveness in organizations in general and in technological companies in particular being the most important capital is the effective employee.

Second, the importance of this research comes from that none of the technological companies in Lebanon apply Balanced Scorecard despite its vital necessity and none of the authors studied the relation between BSC and increasing employees' effectiveness -as fare as the author knows-.

\section{Problem statement:-}

1. Is applying Balanced Scorecard at the Lebanese Technological companies possible?

2. Will applying Balanced Scorecard at the Lebanese Technological companies have a good impact on employees? 
3. Will applying Balanced Scorecard at the Lebanese Technological companies have a good impact on companies?

Purpose of the Study:-

1. Enhancing the awareness about the importance of BSC in general and its special importance in the Lebanese Technological companies.

2. Explaining the application steps.

3. Trying to apply BSC in some Lebanese Technological companies.

4. Improving employees' performance.

\section{Research Hypothesis:-}

The first main hypothesis:-

There is a statistically-denoted relationship at a functional level $(\mathrm{a}=0.05)$ between Balanced Scorecard variables and an increase in employee's effectiveness in technological companies in North Lebanon.

The second main hypothesis:-

There are statistically-denoted discrepancies at a functional level $(\mathrm{a}=0.05)$ of the response average of the subjects related to improving the employees' effectiveness using balanced scorecard related to personal variables (sex, department, position, years of experience, salary).

The study sample:

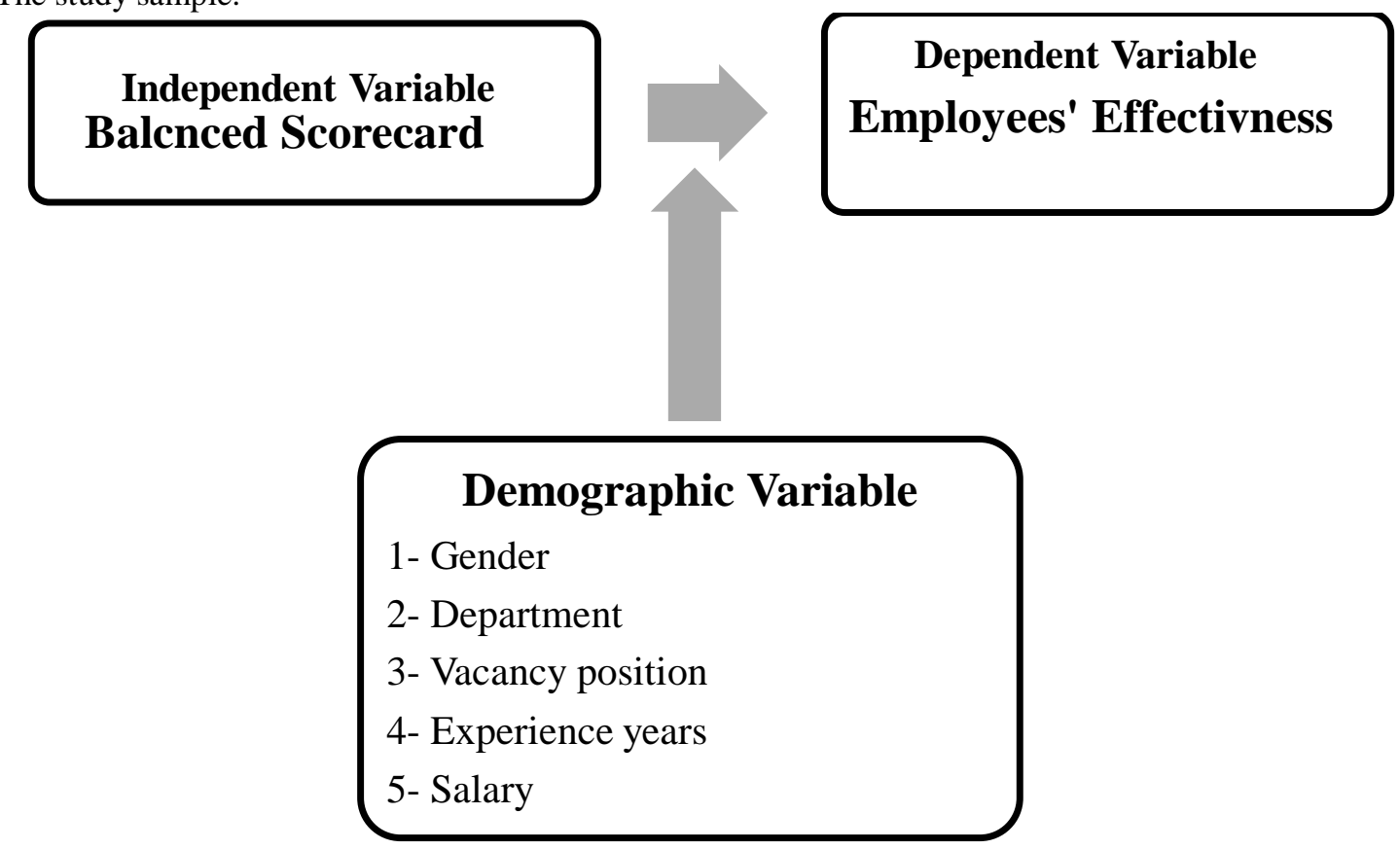

\section{Review of Literature:-}

(Hamad Abu-Jazar, 2012), Identifying the extent of using BSC as a tool to evaluate the performance of the Palestine Islamic Bank. ${ }^{1}$

The study aimed to identify the extent of use of BSC as a tool to evaluate the performance of the Palestine Islamic Bank, and determine the relation of variables of the study with the performance of the bank. The study resulted a positive impact for BSC four dimensions on the performance of the bank but a negative impact of the social dimension. The study recommended to adopt a model of BSC and create conditions for the implementation process.

جزر، (2012) أبو حمد أحمد حمد1 
(Seraj Alshalmany, 2012), Availability of Constituents of Implementing Balance Scorecard Approach for Measuring and Evaluating the Performance of Libyan Service Companies.

The study attempts to determine balance scorecard elements and their availability in Libyan service companies. The study resulted the availability of elements of implementing BSC approach for measuring and evaluating the performance of Libyan service companies. The main recommendation is to implement BSC in order to keep pace with new developments in modern business context.

(Adel Jawad Al-rafati, 2011), The ability of community health organizations in Gaza Strip to apply balanced scorecard as an instrument to measure and evaluate financial performance.

The study aimed at showing and measuring BSC at the health community organizations in Gaza Strip in order to measure financial performance. The result of the study shows that the ingredients of applying BSC is available by "76.18\%", and that applying BSC increases financial performance effectiveness by \%72.13. The study recommended enhancing the application of BSC at the health sector in order to increase the ability to measure financial performance. It also recommended restructuring the four dimensions by replacing the customer perspective with "targeted group perspective" taking into consideration achieving targeted development strategy for these groups. Lastly, the study recommended replacing the financial perspective with "Donors perspective" because it provides money.

(Mohamed Al-Fayez, 2011), Using the Strategic Assessment Approach to measure, Performance using Balanced Scorecard ${ }^{2}$

The study aimed to Using the Strategic Assessment Approach to measure Performance using BSC. Results:

1. There is a significant impact of organizational reality (organizational structure, institutional culture, Executive Team and organizational climate) in improving Jordanian Ministry of Interior Performance at level (0.05).

2. There is a significant impact of available resources (Human Resource; communication; technological; Cross Functional) to improve performance.

3. There is a significant impact of cognitive resources (customers' knowledge; business knowledge; financial knowledge) to improve performance.

4. There is a significant impact of planning knowledge (Corporate Planning; Current Strategy; Planning System; Current Plan) to improve performance.

\section{Recommendation:-}

1- Working to improve and develop work procedures in order to motivate employees to do their work effectively, and allows the practice of various styles of contemporary management. 2- Enhancing decision making participation, in order to reflect empowerment concept.

(Nasar AL-Ajmi, 2010), Building a Proposed Model to Measure the Impact of Intellectual Capital on Performance Efficiency

The study aimed to building a proposed model to measure the impact of intellectual capital on performance efficiency

Recommendation: 1- Paying more attention with intellectual capital because of its impact on the long term to improve performance. 2- Improving performance efficiency level and identify weaknesses points in performance levels by connecting variables that affect each other.

(Athmar Abd Alrazak Mohammad, 2008), The Reflections of Integration Strategy Implementation and Business Reengineering on Strategic Performance By using a balance Scorecard.

The study focuses on the reflection of implementing an integrated strategy and business reengineering strategy on the strategic performance

Result:- Implementation this effect significantly on strategic performance through the four perspectives

Recommendation:- 1- To adopt the implication of strategic and managerial thought in remedy of various organizational phenomena namely, the modern strategies in change, which include integration strategy and business reengineering strategy 2-Developing system to measure performance by studying conditioning and applied the model of balance scorecard.

2011) (محمد خلف الفايز 2011) 
Journals and Articles:-

Shadi Ebrahimi Mehrabani, Maziar Shajari, Relationship between Employee Empowerment and Employee Effectiveness, Service Science and Management Research (SSMR), December 2013

The focus of this research is on introducing and testing a model to show the relationship between employee empowerment and employee effectiveness. Structure equation modeling (SEM) analysis based on 203 questionnaires, was used to test the model. A post-hoc analysis based on three interviews was done in order to get more explanations about the results of the study.

Further researches are recommended to extend the bounds of the current study into additional geographical populations, choosing more organizations or different types of organizations in order to test the results of the model.

Salah Alhyari et.al, Performance evaluation of e-government services using balanced scorecard, an empirical study in Jordan, (2013)

The purpose of this paper is to emphasize on a balance between quantitative and qualitative measures, and examine the use of Balanced Scorecard to evaluate and estimate the performance of information and communication technologies (ICT) in delivering valuable e-government services through the internet. Data were collected by means of a 383 survey questionnaire including common customers, employees of e-government, and employees from the IT sector.

The results show that the Balanced Scorecard factors fit very well with monitoring and measuring the performance of e-government in Jordan, and also in evaluating their success in IT project investments.

Yael Perlman, Causal Relationships in the Balanced Scorecard: A Path Analysis Approach, February 15, 2013.

We use path analysis to identify causal relationships between different performance measures in each of the four perspectives defined in the balanced scorecard and examine the influence of time lag on relationships between perspectives. We analyze performance data from a real high-tech company. Our results point to a direct relationship between leading measures in the learning and growth perspective and lagging measures in the financial perspective.

Our findings also support the existence of a path of:

"Learning $\rightarrow$ Production Efficiency $\rightarrow$ Quality", reflecting the fact that the more the organization invests in learning and in developing its human capital, the better the production efficiency and product quality will be in the same year. We identify an additional direct path: "Customer Service $\rightarrow$ Profit", reflecting a significant positive relationship between the customer and profit in the same year. Finally a "Growth $\rightarrow$ Sales" path exists implies that improvement in the growth of the firm is followed by a positive effect on the firm's sales one year later.

(Muhammad Ehsan Malik, Muhammad Mudasar Ghafoor, and Salman Naseer, 2011) Organizational Effectiveness

This paper provides an impact of employee's performance and employee's motivation toward organizational effectiveness. It examines to what extent the role of employee's performance, their motivation and the environment of organization influence organizational effectiveness particularly in telecommunication and banking sector. The study sample was 103 questionnaires. Results showed that increased employee's performance accelerate organizational effectiveness. As employees get self-motivation, the organizational effectiveness moves in a positive way. Moreover, this study indicates that the effective organizational environment promotes the effectiveness of the organization.

Evaluation of former studies and the difference between current and former studies:In comparison between current and former studies:

Similarities:-

Current study depended on former studies. It started where others ended. Some studies were used directly as a reference and others were used indirectly to give the author a wider and a complete picture of the whole subject.

\section{Differences:-}

1. As far as the author knows, none of the former studies raised the subject of increasing employee's effectiveness using BSC.

2. As far as the author also knows none of the former authors wrote a thesis about employees' effectiveness, rather they used to mention it only in few lines or maximum few pages.

3. Current study mentioned the four perspectives in details, while former thesises mentioned it in short in few pages -most two to four pages-. 
4. None of the former studies applied BSC on IT companies.

5. Most studies focused on using BSC to measure performance and the ability of organizations to apply BSC.

6. Most thesises focuses on the financial perspective of BSC. They were also used studied it to have a master or $\mathrm{PhD}$ degree in accounting and some in marketing but not in human resources management.

\section{The Theoretical Part:-}

\section{Job Description:-}

In simple words, in order to increase effectiveness, we have first to measure old performance depending on job description as shown in form (1). That is why the author talks about three points: job description, performance management, effectiveness and efficiency.

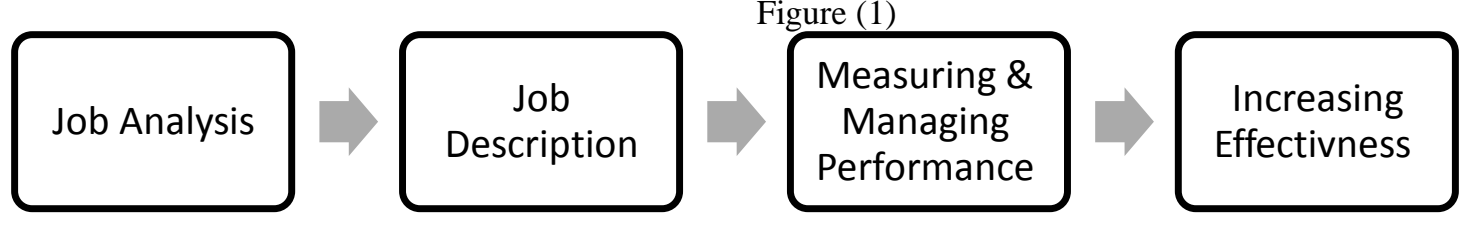

Source: The author

Definitions: (Adnan, 2006, P. 32)

Job analysis: "A systematic way to gather and analyze information about the content and the human requirements of jobs, and the context in which jobs are performed".

Job descriptions: "A written description that summarizes the most important features of a job, including a description of the work that details the required tasks, knowledge, skills, abilities, responsibilities, and reporting structure".

Figure (2), Potential Uses of Job Analysis and Job Description

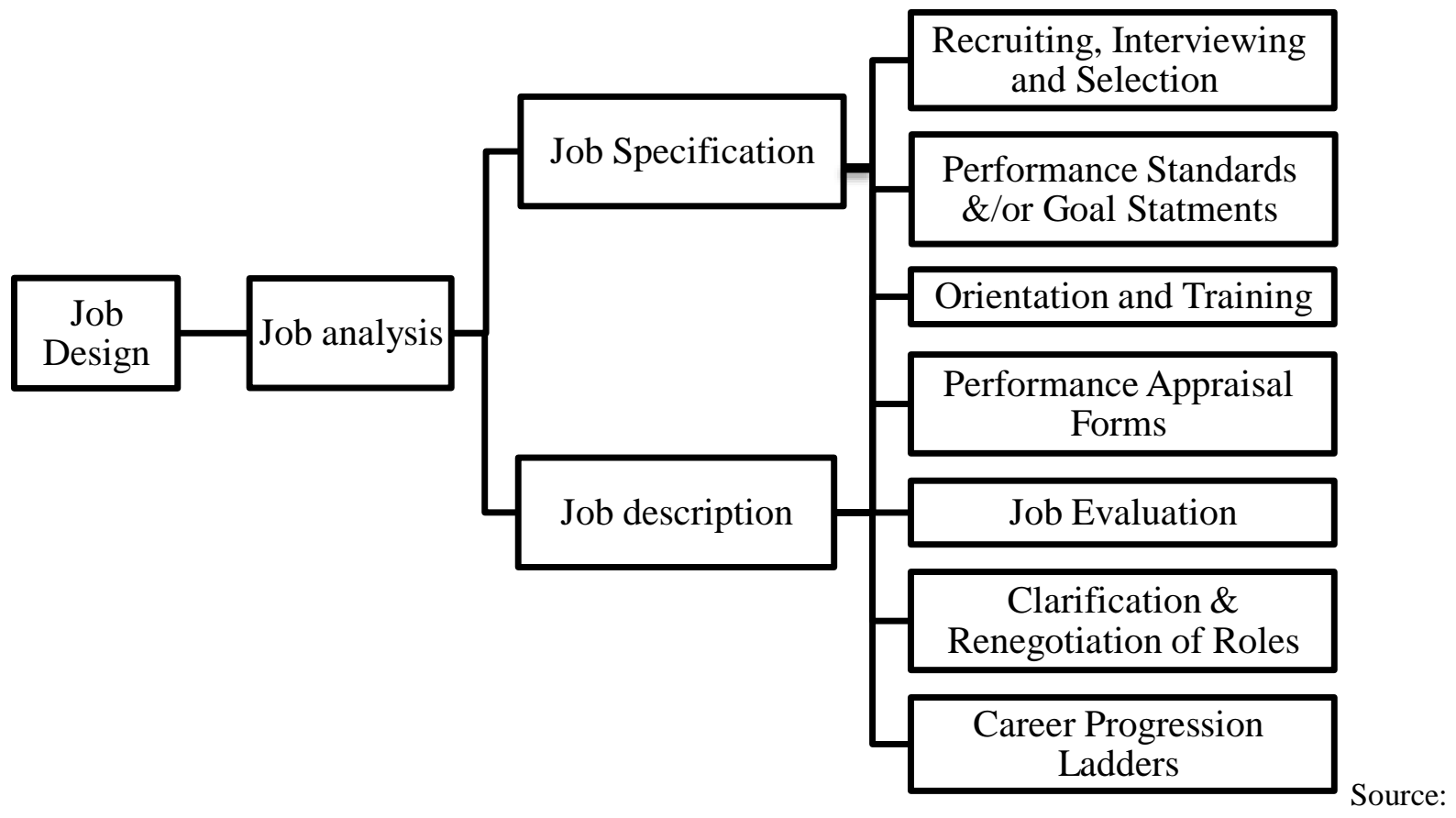

(Abed Albaree Doura 2010)

As shown in figure (2) that Job analysis is the mother from which job description and job specification result from. The form shows us also the main uses of job analysis such as recruiting, training, and measuring and managing performance. Lastly, in short, it is good to refer that there are three ways to gather information in order to do job 
analysis: "interviews" with the employee and his direct manager, "questionnaire" filled by the employee, and "analysis notice" to the way a certain work is performed. (Abed Albaree Doura 2010) ${ }^{3}$

\section{Performance Management:-}

Performance is considered a vital and essential concept in work organizations. It is also the most sensitive perspective that the presence of an organization revolves around. It is the foundation stone of the entity and existence of any organization.

Performance Management: One of the best definitions of performance management is: "It refers to any management process intended to control, direct, and increase the performance of employees working in an organization". (The Practitioner's Model for HRM, SHRM, HR content, 2010)

It is an ongoing process that starts with planning to achieve organizational objectives and goes on to monitoring then developing through training, then evaluating and ending with rewarding high performance and the process goes on and on as shown in figure (3): (Ameer Sardar Kewkha-Bashid, 2012, P. 42)

The evaluations of training programs are without a doubt the most important step in the training process. (Unit - 1: Introduction to Human Resource Management)

Figure 3:- the Performance Management Process

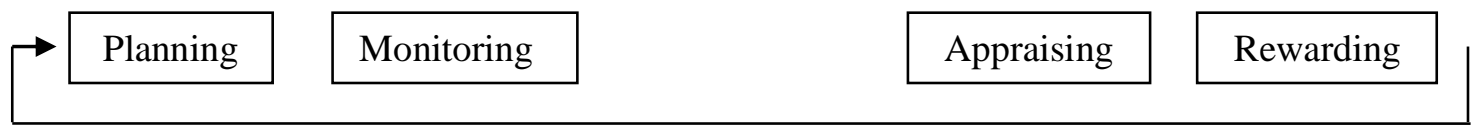

Source: (Ameer Sardar Kewkha-Bashid, 2012)

Measuring Performance: It is 'Studying and analyzing employees' performance and noticing their attitude and behavior at work in order to judge their success and their efficiency level in doing their jobs, in addition to judging the possibility of personal development of employees in the future and bearing higher responsibilities or shifting him to another job".

\section{Effectiveness And Efficiency:-}

Effectiveness: To Do Right Things

Efficiency: To Do Things Right

Effectiveness: is through employee performance \& employee satisfaction (Shadi Ebrahimi Mehrabani and Maziar Shajari, 2013)

Effectiveness: leads to reducing administrative burden, increasing user value and satisfaction, more inclusive public services (Patrick Wauters and Barbara Lörincz, 2008)

Effectiveness Criteria: Productivity, Satisfaction, Manager Judgments (Michael A. Campion, Gina J. Medsker, 1993)

Possible Outcomes from Effective Performance Management:

1. "Clarifying job responsibilities and expectations.

2. Enhancing individual and group productivity.

3. Developing employee capabilities fully through effective feedback and coaching.

4. Driving behavior to align with the organization's core values, goals and strategy.

5. Providing a basis for making operational human capital decisions (e.g., pay).

6. Improving communication between employees and managers.

Effective performance management systems provide behavioral standards that describe what is expected of employees in key competency areas. (Elaine D. Pulakos, 2004)

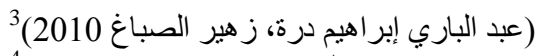

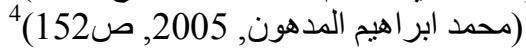




\section{Measuring effectiveness:-}

There are 2 ways:

1. $\frac{\text { Achieving results }}{\text { expected results }}$ This way is to measure achieving results.

2. $\frac{\text { Capabilities used }}{\text { expected capabilities }}$ from achieving results.

Efficiency is related to inputs outputs relation; it can be achieved by either increasing outputs with the same input, or producing the same output from less quantities of input (doing things in a right way) i.e. Best results with least costs while effectiveness means doing the right things. (Maher Banat, 2002) ${ }^{5}$

\section{Conclusion:-}

A job description identifies essential and non-essential tasks that are assigned to a specific position. It also identifies reporting relationships and may also describe required qualifications, minimum requirements, working conditions, and desirable qualifications. Supervisors are responsible for developing and maintaining accurate and current job descriptions for their staff. The duties should be appropriate for the classification and consistent with the class specification. Lastly, it is good to refer that the one who wants to make job description and assessment to the employee and use Balance Scorecard must be trained enough in order to do his duties as needed.

Lastly, the author sees that Achieving and meeting tasks of job description indicates effectiveness. Therefore, each organization can write the criteria that it needs in the job description in order to compare between what is needed and what is achieved and therefore measure the effectiveness of each employee requirements.

\section{Balanced Scorecard:- Introduction:-}

In response to the dissatisfaction with traditional performance management systems, a number of $\mathrm{PM}^{6}$ models have been developed in the recent past. The rise of the total quality management (TQM) for example, drew new direction in business by focusing on the customer and considering the quality of products and services as a means of sustaining competitive advantage. Yet, the problem was integrating non-financial measures with financial measures effectively. $^{7}$

In 1990, David P. Norton and Robert S. Kaplan established "Balanced Scorecard" to be a new framework for integrating measures derived from strategy. It provides executives with a comprehensive framework that translates a company's vision and strategy into a coherent set of performance measures. The real power of BSC, however, occurs when it is transformed from a measurement to a management system. After implementing, BSC was developed to align strategy, then manage strategy and become the cornerstone of an organization's management systems in which we find the true meaning of "Learning Organization".

From the companies that were surveyed almost $60 \%$ of the very large companies and $40 \%$ of the large companies use BSC as a performance management tool. In addition, only $25 \%$ of the small companies use the model of BSC as a performance management tool (George Giannopoulos, et al, 2013)

Financial Perspective:-

"How the company wishes to be perceived by its shareholders." (Yael Perlman, 2013)

Figure 4:- Strategic Themes for the financial Perspective

Source: The author.

(ماهر صالح بنات، 2002، ص67 - 69)5

${ }^{7}$ (Mohamed Majed Kara Mohamed, 2006, p. 8)

${ }^{6} \mathrm{PM}$ : performance management 
Revenue growth and mix:- In short, an organization can do this by developing the product itself through producing new products and services or a new pricing strategy. Also, looking for new customer and markets and strengthening relations with them. Sales growth rates and market share are the common measure for revenue growth.

Cost Reduction/ Productivity Improvement:- It is done by increasing revenue productivity especially in the growth stage in order to cover expenses, having higher operating margin through reducing costs, and the easiest way to reduce cost is to reduce the unit cost, improving channel mix order to communicate with customers, and lastly by reducing operating expenses without affecting quality, performance, or responding to customers.

Asset Utilization / Investment Strategy:- by shortening time needed to change an account payable into account receivable, and improving capital investment procedures by improving productivity

Financial indicators: They can be divided into 5 types: Liquidity ratios, Asset turnover ratios, Financial leverage ratios, Profitability ratios and Dividend policy ratios (John Leslie et al, 2002) (Edward Fields, 2002) (John J. Wild, K.R. et al, 2007) as shown in the figure:

Figure 5:-Financial Ratios

Source: The author. ${ }^{8}$

Internal - Business - Process Perspective:-

"What should we be best at in order to satisfy its shareholders and customers" (https://www.youtube.com/watch?v=M_IlOlywryw) (Yael, 2013, P.70)

This perspective starts from "Customer need identification" and goes throw "innovation process" which is identifying the market and creating the product or service, then "operation process" by building and delivering the product/ service, then "Postsale service process" by serving the customer, and ends with "customer need satisfaction". (Kaplan \& Norton, 1996a) as shown in figure

Figure 6:- Internal-Business-Process value chain ${ }^{9}$

Source: The author

\section{Customer Perspective:-}

"How the company wishes to be perceived by its customers." (Yael Perlman, 2013)

"How do our customers see us?" (https://www.youtube.com/watch?v=M_IlOlywryw)

Customer Perspective Core Measurement Group:

Figure 7:-The Customer Perspective-Core Measures

Source: Kaplan \& Norton (1996a)

Starting from:-

1. Market Segmentation: whether Macro market symmetric or dissymmetric. ${ }^{10}$ This leads to:

2. Retaining Customers: through using tools such as: ${ }^{11}$

3. Primary Retention: this way strengthens the relation with customers on the short time through granting them some incentives.

4. Advanced Retention: to strengthen the social relation with customers on the long time through integral offerings basically needed.

5. Distinct retention: a more advanced way to keep relations and retain customers through financial privileges and social relations which leads to more integral relations based on accurate information. This leads to more satisfied and more loyal customer which in turn leads to more profits to the organization on the long run.

\footnotetext{
${ }^{8}$ To go into details go back to (thesis)

${ }^{9}$ the author

${ }^{10}$ (أيمن علي عمر، (2007)

${ }^{11}$ (منال عبد الكريم، عين، 2012)
} 
6. Customer Acquisition: It is measured by the number of new customers, or total sales for these customers in the targeted markets"12.

7. Customer Satisfaction: Indicators of prices, quality, delivery speed, and mutual trust determine the role and level of satisfaction. ${ }^{13}$

8. All of these lead to Customer Profitability:

\section{Learning And Growth Perspective:-}

"How can we improve and create value". 14

Categories of Learning and Growth Perspective:

Upon building up in Balanced Scorecard, there are three categories of Learning and Growth Perspective as shown in the chart:

Source: The author

Figure (8): Learning and Growth Perspective

After going into the details of each perspective, it is necessary to refer that the four perspectives are and integrated process where the strength in one leads to the strength of another. It is also necessary to refer that there are many other divisions for the perspective such as what "Norton and Kaplan" mention in their book "Strategy Maps":

Figure (9): A Strategy Map Represents How the Organization Creates Value

Source: Kaplan and Norton (2004)

Linking BSC with effectiveness:-

The idea of the research is that in order to increase effectiveness we have first to measure old performance depending on job analysis. Therefore, job description is considered as KPI we depend upon to measure performance and increase effectiveness depending on it.

The three measures (financial, customer, and internal process) lead to increasing the performance of the organization directly and indirectly to increasing the performance of the employee. On the other hand, "learning and growth perspective" leads directly to increasing employees' satisfaction, retention, productivity, and effectiveness and indirectly to this to increasing the effectiveness of the organization.

Therefore, the three perspectives lead to rising the effectiveness of the organization and this is reflected on employees' effectiveness. On the other hand, learning and growth perspective leads directly to raising employees' effectiveness and this is reflected on the effectiveness of the organization.

On the other hand, raising the employees' effectiveness leads to raising the effectiveness of the organization. Therefore, the relation between all the four perspectives is interactive. This is clearer in service organizations where employees have direct contact with customers. Therefore, employees' satisfaction leads to customer satisfaction. On the contrary, customer satisfaction leads to employee and organization satisfaction.

In simple words, if the company applied the measures of $\mathrm{BSC}$, the organization could measure performance and as a result increase performance.

For example, (cost, quality, and cycle time) are measures that have a role in measuring performance and raising employees' effectiveness

The chart concludes the idea:

Figure (10): BSC \& Performance

Source: The author

Therefore, satisfaction leads to $\rightarrow$ productivity and retention $\rightarrow$ results $\rightarrow$ these results lead to increasing employee's effectiveness

\footnotetext{
12 (منال عبد الكريم، 2012)

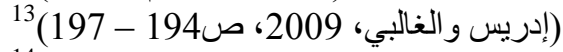

14 https://www.youtube.com/watch?v=M_IlOlywryw
} 
Figure (11): Linking BSC with effectiveness

Source: The author

Conclusion:

Wherever you start this leads to increasing employees' effectiveness and the strength in one of these components leads to the strength in the other components and to the strength of increasing employees' effectiveness as a consequence.

BSC calls for motivating employees, increasing their performance and satisfaction which leads to achieving organizational objectives. Therefore applying BSC increases employees' effectiveness

Employee Effectiveness is: Employee Performance and satisfaction and this is part of BSC. As a conclusion, effectiveness is "Goal Based" while efficiency means "efficiency of resources and having enough experience to do the work". For a strategy to achieve its goals, it must be effective. Using BSC helps in achieving strategic goals through the four perspectives. That is why vision, mission, and goals must be defined clearly. Having no plan and goals then there is no measuring which means that we do not know whether they were effective or not.

\section{Analysis And Results:-}

Describing the study population:-

First: Targeted population:-

The study dealt with all managers and employees in the targeted companies. A random sample of 50 persons covering all departments of maintenance, accounting, follow up, programming and sails was taken. The sample represents nearly $(90 \%)$ of the community of the study. Targeted employees are tested by handling (110) questionnaires and having back (50).

\section{Second: How to measure variables:-}

The analytical-descriptive method was used which is known as a try to achieve accurate and detailed knowledge of the components of the problem to reach better and more precise understanding or setting future policies and measures related to it. "This method is usually used when we previously know the dimensions of a certain phenomenon" "15. Questionnaire is used depending on random sample way where a sample of employees and managers was taken to give their opinion by answering the questions depending on Lecard fifth measurement indicator

Table 1:-Alpha Crombakh:

\begin{tabular}{|l|c|c|}
\hline \multicolumn{1}{|c|}{ The perspectives } & Correlation person & $(\mathrm{sig})$ \\
\hline Financial perspective & $0.604 * *$ & 0.000 \\
\hline Customer perspective & $0.705^{* *}$ & 0.000 \\
\hline Internal business process perspective & $0.842^{* *}$ & 0.000 \\
\hline Learning and growth perspective & $0.799^{*}$ & 0.000 \\
\hline Employee effectiveness perspective & $0.861 * *$ & 0.000 \\
\hline
\end{tabular}

The former table shows that the questionnaire is cohesive and appropriate to allocate distribution and gather information.

Table 2:-Testing the reliability of the questionnaire: 16

\begin{tabular}{|c|c|}
\hline Cronbach's alpha & N of items \\
\hline 0.874 & 55 \\
\hline
\end{tabular}

The stability of the questionnaire is 0.87 and it is a very good result which means that in case of applying it in similar circumstances then we will get the same results.

Table 3:-Testing Normal Distribution:

\begin{tabular}{|l|l|l|}
\hline \multicolumn{1}{|c|}{ Perspectives } & \multicolumn{1}{|c|}{ Kolmogorov-Smirnova } & Results \\
\cline { 2 - 3 } & \multicolumn{1}{|c|}{ Sig. } & \\
\hline Financial perspective & 0.20 & There is normal distribution \\
\hline
\end{tabular}

\footnotetext{
، ص122) صأحمد حسن الرفاعي، (2009)

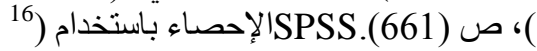




\begin{tabular}{|l|l|l|}
\hline Customer perspective & 0.20 & There is normal distribution \\
\hline Internal business process perspective & 0.115 & There is normal distribution \\
\hline Learning and growth perspective & 0.160 & There is normal distribution \\
\hline Employee effectiveness perspective & 0.112 & There is normal distribution \\
\hline All & 0.075 & There is normal distribution \\
\hline
\end{tabular}

Normal Distribution is tested and results were more than 0.05 . This indicates that:

1. The sample represents the community i.e. the companies in which the study took place, represent all technological companies working in North Lebanon.

2. Hypotheses are true for testing and application.

3. Results are true and represent respondents' opinions.

Table 4:-Statistical analysis of characters of the study sample

\begin{tabular}{|c|c|c|c|c|c|c|}
\hline Factor & Variables & Frequency & Percent & Mean & $\begin{array}{c}\text { Std. } \\
\text { Deviation }\end{array}$ & Mode \\
\hline \multirow[t]{2}{*}{ Gender } & Male & 43 & $86 \%$ & \multirow[t]{2}{*}{1.14} & \multirow[t]{2}{*}{0.35} & \multirow[t]{2}{*}{1.00} \\
\hline & Female & 7 & $14 \%$ & & & \\
\hline \multirow[t]{6}{*}{ Department } & Maintenance & 18 & $36 \%$ & \multirow[t]{6}{*}{2.76} & \multirow[t]{6}{*}{1.34} & \multirow[t]{6}{*}{3.00} \\
\hline & Follow up & 11 & $22 \%$ & & & \\
\hline & Programming & 10 & $20 \%$ & & & \\
\hline & Sales & 6 & $12 \%$ & & & \\
\hline & Other & 3 & $6 \%$ & & & \\
\hline & Accounting & 2 & $4 \%$ & & & \\
\hline \multirow[t]{3}{*}{ State } & Employees & 36 & $76 \%$ & \multirow[t]{3}{*}{2.64} & \multirow[t]{3}{*}{0.692} & \multirow[t]{3}{*}{3.00} \\
\hline & Middle & 6 & $12 \%$ & & & \\
\hline & High management & 6 & $12 \%$ & & & \\
\hline \multirow[t]{4}{*}{ Experience } & 6 years and more & 16 & $32 \%$ & \multirow[t]{4}{*}{2.50} & \multirow[t]{4}{*}{1.21} & \multirow[t]{4}{*}{4.00} \\
\hline & Less than a year & 14 & $28 \%$ & & & \\
\hline & $\begin{array}{l}\text { From } 1 \text { to less than } 3 \\
\text { years }\end{array}$ & 13 & $26 \%$ & & & \\
\hline & $\begin{array}{l}\text { From } 3 \text { to less than } 6 \\
\text { years }\end{array}$ & 7 & $14 \%$ & & & \\
\hline \multirow[t]{3}{*}{ Salary } & From $\$ 501$ to $\$ 1000$ & 26 & $52 \%$ & \multirow[t]{3}{*}{1.88} & \multirow[t]{3}{*}{0.689} & \multirow[t]{3}{*}{2.00} \\
\hline & Less than $\$ 500$ & 15 & $30 \%$ & & & \\
\hline & More than $\$ 1000$ & 9 & $18 \%$ & & & \\
\hline
\end{tabular}

\section{Gender:-}

From the table we see that males are $86 \%$ while females are only $14 \%$. Nowadays both males and females have somehow the same rights such as learning and working, yet males are in need to work more than females, in addition to social traditions that have some effect "masculine society".

\section{Department:-}

Because all departments are in need to maintenance department, we see that their percentage is the highest while we see that the least average is the accounting department which is sufficient to the work of the company.

State:- We see that most respondents are employees (76\%) and that (12\%) are high and middle management.

Experience:- Retaining employees is an indicator of the strength of the company. The strength of the company is with this $32 \%$. At the same time it is clear from the table that the company is keen to have new blood and new experiences whose salaries are usually low and the cost of their investment is low.

Salary:- In comparison with "experience", we can notice that the percent of employees who are less than a year is $28 \%$ which is near to the percentage of those who take less than $\$ 500$. Therefore, years of experience and salary play a role in the ability of employee to learn and grow and in his effectiveness -as we will see later. 
Table 5:-Statistical Analysis for Study Phrases:

\begin{tabular}{|l|l|l|l|}
\hline \multicolumn{1}{|c|}{ Perspective } & Mean & Std. Devi & Q. Percent \\
\hline Financial perspective & 3.75 & 0.34 & 0.75 \\
\hline Customer perspective & 3.84 & 0.52 & 0.76 \\
\hline Internal process & 3.49 & 0.60 & 0.69 \\
\hline Learning \& growth & 3.57 & 1.07 & 0.71 \\
\hline Effectiveness & 3.60 & 0.58 & 0.72 \\
\hline
\end{tabular}

From Table (5) we see that respondents agree on the content of the phrases in the financial, customer, internal process, and learning \& growth perspectives where the mean of the phrases were more than (3.4) and less than (4.2) and the question percentage were more than $(60 \%)$. This also indicates that respondents are able to form a clear vision toward these perspectives. Lastly, this indicates that respondents agree that applying Balanced Scorecard plays a vital role in increasing employees' effectiveness.

Statistical Analysis for Study Hypothesis:-

Table 6:-Pearson correlation between BSC perspectives and employees' effectiveness

\begin{tabular}{|l|c|c|c|}
\hline \multicolumn{1}{|c|}{ Variables } & Pearson correlation & Sig. (1-tailed) & Number of respondents \\
\hline Financial perspective & $0.41^{* *}$ & 0.003 & 50 \\
\hline Customer perspective & $0.55^{* *}$ & 0.000 & 50 \\
\hline Internal business process perspective & $0.77^{* *}$ & 0.000 & 50 \\
\hline Learning and growth perspective & $0.55^{* *}$ & 0.000 & 50 \\
\hline
\end{tabular}

There is a statistically-denoted relationship between the financial perspective and an increase employee's effectiveness in technology companies in North Lebanon.

Pearson correlation is used show the relation between financial perspective and employee effectiveness. Table (6) shows that Pearson correlation equals $(0.41)$ and the value semantics is $(0.000)$ which is less than $(0.05)$ which means that there is positive middle relation between the financial perspective and employee effectiveness. This means that the financial perspective increases employees' effectiveness with $41 \%$.

There is a statistically-denoted relationship between customer perspective and increasing employee's effectiveness in the technology companies working in North Lebanon.

Table (6) shows that Pearson correlation equals (0.55) which is between (50-70)and the value semantics is $(0.000)$ which is less than (0.05) which means that there is positive good relation between customer perspective and employee effectiveness at significance level (0.05). This means that the customer perspective increases employees' effectiveness with $55 \%$.

There is a statistically-denoted relationship between internal business processes perspective and increasing employee's effectiveness in the technology companies working in North Lebanon.

Table (6) shows that Pearson correlation equals $\left(0.77^{* *}\right)$ and the value semantics is $(0.000)$ which is less than $(0.05)$ which is more than (70) which means that there is positive strong relation between internal business processes perspective and employee effectiveness at significance level (0.05). This means that the internal business processes perspective increases employees' effectiveness with $77 \%$.

There is a statistically-denoted relationship between learning and growth perspective and increasing employee's effectiveness in the technology companies working in North Lebanon

Table (6) shows that Pearson correlation equals $\left(0.55^{* *}\right)$ and the value semantics is $(0.000)$ which is less than $(0.05)$ which means that there is positive good relation between learning and growth perspective and employee effectiveness at significance level (0.05). This means that the learning and growth perspective increases employees' effectiveness with $55 \%$.

\section{Proving Demographic Hypothesis:-}

There are statistically-denoted discrepancies at a functional level $(\mathrm{a}=0.05)$ of the response average of the subjects related to improving the employees' effectiveness using balanced scorecard related to personal variables (sex, department, position, years of experience, salary). 
Gender:-

Table 7:-mean according to gender

\begin{tabular}{|c|c|c|c|}
\hline Gender & Number & Mean & Std. Deviation \\
\hline Male & 43 & 3.63 & 0.50 \\
\hline Female & 7 & 3.77 & 0.29 \\
\hline
\end{tabular}

Table (7) shows that females can respond to increasing employee effectiveness using balanced scorecard more than males. This is a sign of how to divide employees on departments in order to be more effective. Lastly this is evidence that there are statistical significance differences between respondents' reflection to increasing employee effectiveness using balanced scorecard. This assures the $1^{\text {st }}$ demographic hypothesis.

\section{Department:-}

Table 8:- shows difference in mean related with department

\begin{tabular}{|c|c|c|c|c|c|c|}
\hline \multicolumn{1}{|c|}{ Department } & Programming & Follow up & Maintenance & Sales & Accounting & Other \\
\hline Number & 10 & 11 & 18 & 6 & 2 & 3 \\
\hline Mean & 3.67 & 3.38 & 3.72 & 3.89 & 3.83 & 3.55 \\
\hline
\end{tabular}

Table (8) shows that there are statistically-denoted differences between departments. Sales department is the best department to respond to increasing employee effectiveness using balanced scorecard, then accounting, then maintenance, then programming, then other department, and lastly follow up department. This assures the $2^{\text {nd }}$ demographic hypothesis.

Vacancy position:-

Table 9:-shows mean related with vacancy position

\begin{tabular}{|c|c|c|c|}
\hline Categories & High management & Middle management & Employee \\
\hline Number & 6 & 6 & 38 \\
\hline Position & 3.93 & 3.44 & 3.64 \\
\hline
\end{tabular}

Table 9 shows that there are statistically-denoted differences between categories related to vacancy position. High management was the most effective to respond to increasing employee effectiveness using balanced scorecard where mean $=(3.93)$, the mean for employee who came in the second stage $=(3.64)$, and in the last stage came middle management and with a mean of (3.44). This assures the $3^{\text {rd }}$ demographic hypothesis.

\section{Experience years:-}

Table 10:-shows difference in mean related with years of experience

\begin{tabular}{|c|c|c|c|}
\hline Less than a year & From 1 to less than 3 years & From 3 to less than 6 years & 6 years and more \\
\hline 14 & 13 & 7 & 16 \\
\hline 3.77 & 3.57 & 3.45 & 3.70 \\
\hline
\end{tabular}

Table (10) shows that there are differences related to years of experience. The table also shows that those who have less than one year of experience are the best to respond to increasing employee effectiveness using balanced scorecard, then come those who have 6 years and more, then for one to 3 years, and in the last stage came employees of $3-6$ years. This assures the $4^{\text {th }}$ demographic hypothesis.

Salary:-

Table 11:-difference in means according to salary variable

\begin{tabular}{|c|c|c|}
\hline Less than $\$ 500$ & From $\$ 501$ to $\$ 1000$ & More than $\$ 1000$ \\
\hline 15 & 26 & 9 \\
\hline 3.74 & 3.59 & 3.68 \\
\hline
\end{tabular}

Table (11) shows that there are statistically-denoted differences between variables related to salary. Those who take less than $500 \$$ a month were the most effective to respond to increasing employee effectiveness using balanced scorecard. In the second place came people who take from $501-1000 \$$, and in the last stage came those who take more than $1000 \$$ a month. This assures the $5^{\text {th }}$ demographic hypothesis.

\section{Proving the Main Hypothesis:-}

To prove the study hypothesis we used these tests: 
Correlation (r): it is used to measure the strength and the direction of a relation between two variables such as the relation between the financial perspective and employees' effectiveness. For example, in table 29 we can see that BSC alone helps in increasing employees' effectiveness with a rate of $51 \%$ and $49 \%$ result from other factors such as salary, good deed ... etc.

$\left(r^{2}\right)$ : it indicates the responsibility of the independent variable on the change on the dependent variable. For example, in table 30 we can see that financial perspective plays a role of $17 \%$ in increasing employees' effectiveness and $83 \%$ result from other factors.

(t) and (sig): "non-relation" hypothesis is rejected and the alternative hypothesis is accepted if (sig is less than 0.05). "Non-relation" hypothesis is accepted if (sig is more than 0.05) and when the value of $(\mathrm{t})$ is more than (2).

Table 12:-results of (t) test and the correlations (r) to recognize balanced scorecard variables and increasing employee effectiveness in technology companies in North Lebanon

\begin{tabular}{|l|c|c|c|c|}
\hline \multicolumn{1}{|c|}{ Variables } & $\mathrm{T}$ & $\begin{array}{c}\text { Significance level } \\
(\mathrm{sig})\end{array}$ & $\mathrm{R}$ & $\mathrm{R}$ square \\
\hline Financial perspective & 3.16 & 0.003 & 0.41 & 0.17 \\
\hline Customer perspective & 4.58 & 0.000 & 0.552 & 0.30 \\
\hline Internal business process perspective & 8.37 & 0.000 & 0.77 & 0.59 \\
\hline Learning and growth perspective & 4.65 & 0.000 & 0.558 & 0.31 \\
\hline Applying balanced scorecard perspectives & 7.18 & 0.000 & 0.72 & 0.51 \\
\hline
\end{tabular}

\section{The first main hypothesis:-}

There is a statistically-denoted relationship at a functional level $(\mathrm{a}=0.05)$ between balanced scorecard variables and increasing employees' effectiveness in technology companies in North Lebanon.

Results in table (12) show that (r) value indicates that there is a strong correlation between applying balanced scorecard and employee effectiveness where its value is (0.72) and the average of responsibility of balanced scorecard on employee effectiveness is (51\%). As a result we can see that balanced scorecard is responsible for employee effectiveness in a serious and important way.

Back to the hypothesis related with balanced scorecard and employee effectiveness, we can see that (t) value is (7.18) and (sig) value is (0.000) i.e. Less than (0.05). By this, null hypothesis is rejected and the alternative hypothesis is accepted i.e. There is a statistically-denoted relationship at a functional level $(a=0.05)$ between balanced scorecard variables and increasing employees' effectiveness in technology companies in North Lebanon.

\section{The $1^{\text {st }}$ sub-hypothesis:}

There is a statistically-denoted relationship at a functional level $(\mathrm{a}=0.05)$ between the financial perspective and increasing employee's effectiveness in technology companies in North Lebanon.

Results in table (12) indicate that there is a mid correlation between the financial perspective and employee's effectiveness where the value is (0.41) and the average of responsibility of the financial perspective of BSC on employee's effectiveness is (17\%). As a conclusion, the financial perspective of BSC is responsible for employee effectiveness in a serious and important way.

Back to the $1^{\text {st }}$ sub-hypothesis we can see that $(\mathrm{t})$ value is (3.16) and (sig) is $(0.003)$ which is less than $(0.05)$. By this the null hypothesis is rejected and the alternative hypothesis is accepted i.e. There is a statistically-denoted relationship at a functional level $(a=0.05)$ between the financial perspective and increasing employees' effectiveness in technology companies in North Lebanon.

\section{The $2^{\text {nd }}$ sub-hypothesis:}

There is a statistically-denoted relationship at a functional level $(\mathrm{a}=0.05)$ between customer perspective and increasing employee's effectiveness in the technology companies working in North Lebanon.

Results in table (12) indicate that (r) value indicates that there is a strong correlation between customer perspective and employee's effectiveness where value is $(0.552)$. The average of responsibility of customer perspective of BSC 
on employee's effectiveness is (30\%). As a conclusion, the customer perspective of BSC is responsible for employee effectiveness in a serious and important way.

Back to the hypothesis related to customer perspective and employee effectiveness, we can see that (t) value is (4.58) and (sig) value is (0.000) i.e. Less than (0.05). By this, null hypothesis is rejected and the alternative hypothesis is accepted i.e. There is a statistically-denoted relationship at a functional level $(a=0.05)$ between customer perspective and increasing employees' effectiveness in technology companies in North Lebanon.

\section{The $3^{\text {rd }}$ sub-hypothesis:-}

There is a statistically-denoted relationship at a functional level $(\mathrm{a}=0.05)$ between internal processes perspective and increasing employee's effectiveness in the technology companies working in North Lebanon.

Results in table (12) indicate that ( $\mathrm{r}$ ) value indicates that there is a very strong relation between internal processes perspective and employee's effectiveness where value is $(0.77)$. The average of responsibility of internal processes perspective on employee's effectiveness is $(59 \%)$. As a conclusion, internal processes perspective is responsible for employee's effectiveness in a serious and important way.

Back to the hypothesis related with internal processes perspective and employee effectiveness, we can see that (t) value is (8.37) and (sig) value is (0.000) i.e. Less than (0.05). By this, null hypothesis is rejected and the alternative hypothesis is accepted i.e. There is a statistically-denoted relationship at a functional level $(\mathrm{a}=0.05)$ between internal processes perspective and increasing employees' effectiveness in technology companies in North Lebanon.

\section{The $4^{\text {th }}$ sub-hypothesis:-}

There is a statistically-denoted relationship at a functional level $(\mathrm{a}=0.05)$ between learning and growth perspective and increasing employee's effectiveness in the technology companies working in North Lebanon.

Results in table (12) indicate that ( $r$ ) value indicates that there is a strong relation between learning and growth perspective and employee's effectiveness where value is (0.558). The average of responsibility of learning and growth perspective on employee's effectiveness is (31\%). As a conclusion, learning and growth perspective is responsible for employee's effectiveness in a serious and important way.

Back to the hypothesis related with learning and growth perspective and employee's effectiveness, we can see that (t) value is (4.65) and (sig) value is (0.000) i.e. Less than (0.05). By this, null hypothesis is rejected and the alternative hypothesis is accepted i.e. There is a statistically-denoted relationship at a functional level $(a=0.05)$ between learning and growth perspective and increasing employees' effectiveness in technology companies in North Lebanon.

Table 13:-Comparison between current study and Former studies:

\begin{tabular}{|c|c|c|c|c|}
\hline & The study & The perspective & The mean & Std. Deviation \\
\hline 1 & Osama Natheer Ghannam, (2015), & Financial perspective & 3.75 & 0.34 \\
\hline & increasing employees' effectiveness using & Customer perspective & 3.84 & 0.52 \\
\hline & balanced scorecard, Jinan, university, & Internal processes & 3.49 & 0.6 \\
\hline & Lebanon & Learning and growth & 3.57 & 1.07 \\
\hline 2 & Hamad Ahmed Hamad Abu-Jazar, (2012), & Financial perspective & 3.27 & 0.506 \\
\hline & Identifying the extent of using of the & Customer perspective & 3.48 & 0.494 \\
\hline & Balanced Scorecard (BSC) as a tool to & Internal processes & 3.21 & 0.558 \\
\hline & $\begin{array}{l}\text { evaluate the performance of the Palestine } \\
\text { Islamic Bank, Islamic University, Gaza. }^{17}\end{array}$ & Learning and growth & 3.24 & 0.502 \\
\hline 3 & Mohamed Ahmed Mohamed Abu-Kamer, & Financial perspective & 3.98 & - \\
\hline & (2009) Managing the performance of & Customer perspective & 4.09 & - \\
\hline
\end{tabular}

جزر، (2012) أبو حمد أحمد حمد17 


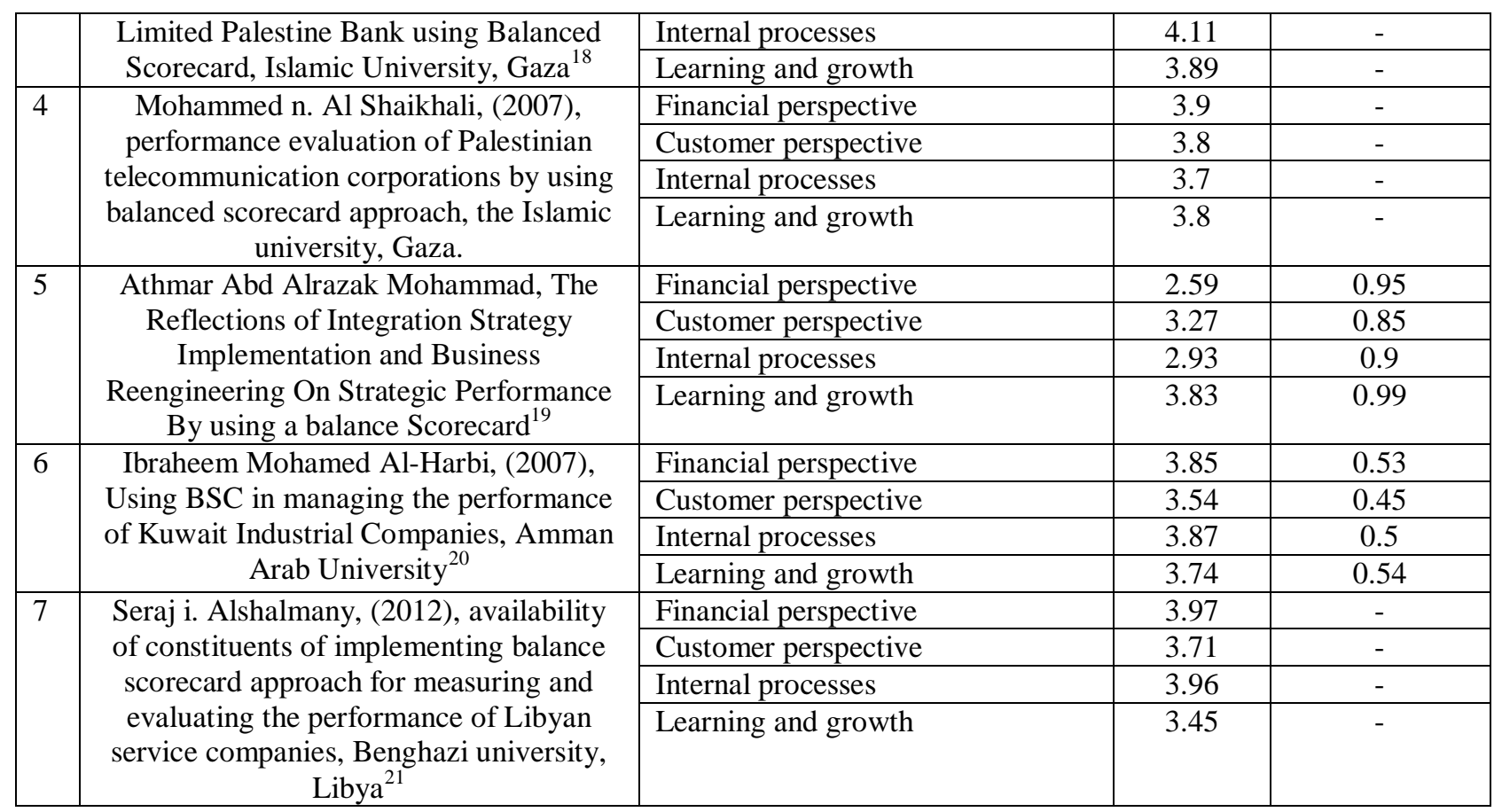

\section{Results:-}

Based on practical study and relying on studying current situation of the companies depending upon meetings, the author reached the following results:

1. There is a statistically-denoted relationship between the financial perspective and increasing employee's effectiveness in technology companies in North Lebanon.

2. There is a statistically-denoted relationship between internal processes perspective and increasing employee's effectiveness in technology companies in North Lebanon.

3. There is a statistically-denoted relationship between customer perspective and increasing employee's effectiveness in the technology companies working in North Lebanon.

4. There is a statistically-denoted relationship between learning and growth perspective and increasing employee's effectiveness in the technology companies working in North Lebanon.

5. There is a statistically-denoted relationship at a functional level $(a=0.05)$ between $B S C$ variables and increasing employee's effectiveness in technology companies in North Lebanon.

6. There is a statistically-denoted relationship at a functional level $(\mathrm{a}=0.05)$ between the financial perspective and increasing employee's effectiveness in technology companies in North Lebanon.

7. There is a statistically-denoted relationship at a functional level $(\mathrm{a}=0.05)$ between internal processes perspective and increasing employee's effectiveness in technology companies in North Lebanon.

8. There is a statistically-denoted relationship at a functional level $(\mathrm{a}=0.05)$ between customer perspective and increasing employee's effectiveness in technology companies in North Lebanon.

9. There is a statistically-denoted relationship at a functional level $(\mathrm{a}=0.05)$ between learning and growth perspective and increasing employee's effectiveness in technology companies in North Lebanon.

10. There are statistically-denoted discrepancies at a functional level $(a=0.05)$ of the response average of the respondents related to improving employee' effectiveness using balanced scorecard related with sex.

11. There are statistically-denoted discrepancies at a functional level $(a=0.05)$ of the response average of the respondents related to improving employee' effectiveness using balanced scorecard related with department.

\footnotetext{
محمدأحمد محمد أبو قمر ، (2009)

أثنمار عبد الرزاق محمد، (2008) 19

إبر اهيم محمد الحربي، (2007)

سر اج الثلماني، (2012)
} 
12. There are statistically-denoted discrepancies at a functional level $(a=0.05)$ of the response average of the respondents related to improving employee' effectiveness using balanced scorecard related with vacancy position.

1. There are statistically-denoted discrepancies at a functional level $(a=0.05)$ of the response average of the respondents related to improving employee' effectiveness using balanced scorecard related with years of experience.

2. There are statistically-denoted discrepancies at a functional level $(a=0.05)$ of the response average of the respondents related to improving employee' effectiveness using balanced scorecard related with salary.

\section{Recommendations:-}

Depending on my study, I recommend to...

1. To apply BSC because it is a practical way to increase employees' effectiveness.

2. To apply BSC because it is an integrated system for strategic management; a developed way for managing, measuring and developing performance.

3. To focus on financial ratios as essential indicators for performance.

4. To focus on the internal processes perspective and use it for increasing employees" effectiveness as the most important perspective

5. Strengthening relations with rivals in order to learn from them, raise standards, serve customers more in order to retain them and increase revenues as a consequence.

6. Developing the marketing strategy depending on a wider and more precise marketing study.

7. Making continuous survey for customers' opinions to measure their satisfaction and use the tools for retaining customers mentioned in the thesis.

8. Investigating customers' reasons for leaving and trying to bring them back.

9. Work hard to keep the good mental state that customers have about the company and try to develop it more and more.

10. Simplifying processes such as communication between departments and reducing work stress to give a wider chance for learning.

11. Conduct more various training methods that meet the needs of high qualified employees due to its vital role in retaining employees.

12. Increase salary depending on a fair measuring performance and not according to manager's view and motivate creative innovative ideas more.

13. To encourage employees' contribution and sharing in making decisions to realize alignment concept.

14. Study employees' needs and wants according to "Maslow's hierarchy" to motivate and give them according to the stage they are in.

15. Activating the role of HR management with focusing on job description, recruitment, measuring performance, training and effective motivation system.

16. Recommendation for new studies is to talk about "Talent Balanced Scorecard".

\section{References:-}

1. Ameer Sardar Kewkha-Bashid, (2012), Impact of Knowledge Sharing on Performance Management in Organizations Using SharePoint Server, Jinan University, Lebanon, Master thesis.

2. Mohamed Majed Kara Mohamed, (2006), Balanced Scorecard Implementation the Learned Lessons, American University, Beirut, Lebanon, master thesis.

3. Seraj I. Alshalmany, (2012), Availability of Constituents of Implementing Balance Scorecard Approach for Measuring and Evaluating the Performance of Libyan Service Companies, An Empirical study on Libyan service companies in both Tripoli and Benghazi, Benghazi University, Libya, master thesis.

\section{Journals and Articles:-}

1. George Giannopoulos, Andrew Holt, Ehsan Khansalar1 \& Stephanie Cleanthous, The Use of the Balanced Scorecard in Small Companies, International Journal of Business and Management; Vol. 8, No. 14; 2013, Published by Canadian Center of Science and Education

2. Lars-Go“ ran Aidemark, Stefano Baraldi, Elin K. Funckand Andreas Jansson, The Importance of Balanced Scorecards in Hospitals, Emerald Group Publishing Limited, Volume20 , ISSN: 1479 3512, 2010, P. 363-385. 
3. Michael A. Campion, Gina J. Medsker, (1993), Relations between Work Group Characteristics and Effectiveness: Implications for Designing Effective Work Groups, Purdue University, West Lafayette, Personnel Psychology, INC.

4. Muhammad Ehsan Malik, Muhammad Mudasar Ghafoor, and Salman Naseer, Organizational Effectiveness, a Case Study of Telecommunication and Banking Sector of Pakistan, Far East Journal of Psychology and Business, January 2011, Vol. 2 No 1

5. Patrick Wauters and Barbara Lörincz, User satisfaction and administrative simplification within the perspective of eGovernment impact: Two faces of the same coin. European Journal of ePractice.

6. Salah Alhyari et.al, Performance evaluation of e-government services using balanced scorecard, an empirical study in Jordan, Emerald Group Publishing Limited, Vol. 20 No. 4, 2013, P. 512-536.

7. Shadi Ebrahimi Mehrabani, Maziar Shajari, Relationship between Employee Empowerment and Employee Effectiveness, Service Science and Management Research (SSMR), December 2013, Volume 2 Issue 4, Islamic Azad University-Dehaghan Branch Isfahan, Iran

8. Yael Perlman, (2013), Causal Relationships in the Balanced Scorecard: A Path Analysis Approach, Bar-Ilan University, Ramat-Gan 52900, Vol. 4, No. 1, ISSN 1923-3965, Israel, February 15.

9. Zdenko Miholcic and Colin Clark, Multiple Performance Measurement in Australian Top 500 Companies, Emerald Group Publishing Limited, Volume 20, ISSN: 1474-7871, 2012, P. 125-150.

\section{Books:-}

1. Adnan, HR glossary From A to Z, 2006 Web Edition, MBA (Management), PAKISTAN, ISBN 92-001-7626-0, P. 32

2. Edward Fields, (2002), The Essentials of finance and Accounting for nonfinancial Managers, ISBN, USA.

3. Elaine D. Pulakos, (2004), Performance Management, A roadmap for developing, implementing and evaluating performance management systems, SHRM Foundation, USA

4. John Leslie Livingstone and Theodore Grossman, (2002), The Portable MBA in Finance and Accounting, $3^{\text {rd }}$ edition, John Wiley and Sons, Inc.New York.

5. John J. Wild, K.R. Subramanyam, Robert F. Halsey, (2007), Financial Statement Analysis, $9^{\text {th }}$ edition, Mc Graw Hill, New York.

6. Robert S. Kaplan \& David P. Norton, (1996a), The Balanced Scorecard, Translating Strategy into Action, USA, Harvard College.

7. Robert S. Kaplan, and David P. Norton, (2004), Strategy Maps, Harvard Business School, USA

8. The Practitioner's Model for HRM, SHRM, HR content,(2010) Curriculum Guidebook for the complete list

Arabic References;-

$$
\begin{aligned}
& \text { الرسائل و الأطاريح: } \\
& \text { إبراهيم محمد الحربي، (2007)، مدى استخدام بطاقة الأداء المتوازن في تقييم الأداء في الشركات الصناعية الكوينية، رسالة ماجستير، جامعة }
\end{aligned}
$$

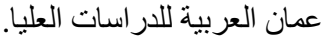

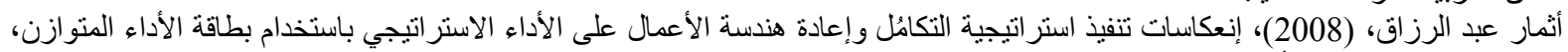

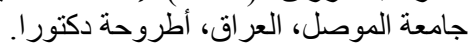

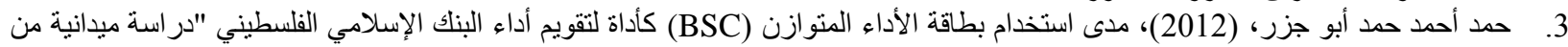

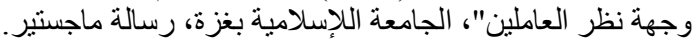

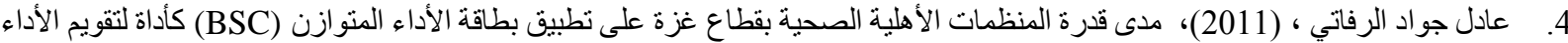

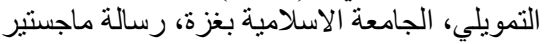

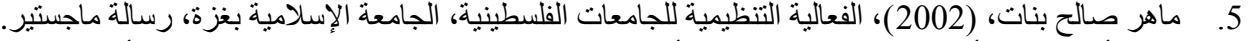

$$
\begin{aligned}
& \text { 6. محمد أحمد محمد أبو قمر، (2009)، ماهرالية، "تقويم أداء بنك فلسطين المحدود باستخدام بطاقة قياس الأداء المتوازن، الجامعة الإسلامية، غزة، رسالة } \\
& \text { 7. محمد خلف الفايز، (2011)، استخدام مدخل التقييم الاستراتيجي لقياس الأداء باستخدام بطاقة التقييم المتوازن، جامعة الثرق الأوسط، الأردن، } \\
& \text { رسالة ماجستير. }
\end{aligned}
$$

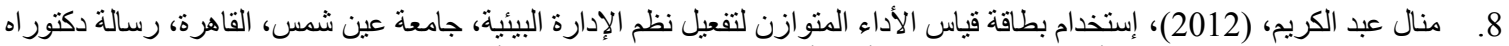

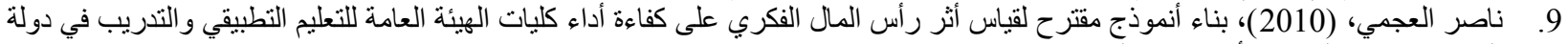

$$
\begin{aligned}
& \text { الكويت، جامعة الثرق الأوسط، رسالة ماجستير. }
\end{aligned}
$$

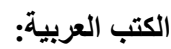

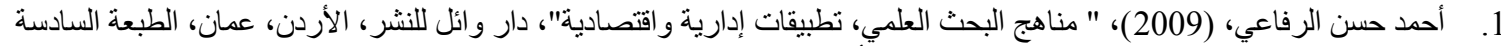

$$
\begin{aligned}
& \text { 2. }
\end{aligned}
$$

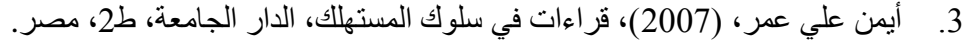


4. عبد الباري إبر اهيم درة، زهير نعيم الصباغ (2010)، إدارة الموارد البشرية في القرن الحادي والعشرين، منحى نظمي، دار وائل، الطبعة الثانية، الأردن

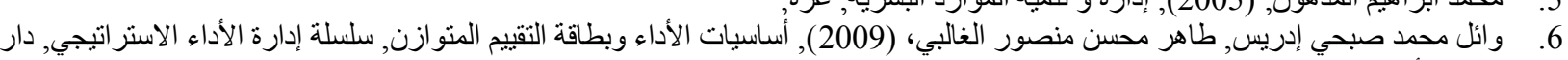
وائل, الأردن

Websites:-

https://www.youtube.com/watch?v=M_IlOlywryw 11/3/2015, 10am 